\title{
LENGTH-WEIGHT RELATIONS OF 46 FISH SPECIES (ACTINOPTERYGII) FROM LOWER SECTIONS OF THE JIALING RIVER, SOUTH-WESTERN CHINA
}

\author{
Long $\mathrm{REN}^{1,2}$, Jinming $\mathrm{WU}^{2}$, Meng $\mathrm{HAO}^{1}$, and Jiabo $\mathrm{ZHANG}^{1^{*}}$ \\ ${ }^{1}$ College of Fisheries, Huazhong Agricultural University, Wuhan, Hubei, China \\ ${ }^{2}$ Key Laboratory of Freshwater Biodiversity Conservation, Ministry of Agriculture of China, Yangtze River Fisheries \\ Research Institute, Chinese Academy of Fishery Sciences, Wuhan, China
}

Ren L., Wu J., Hao M., Zhang J. 2018. Length-weight relations of 46 fish species (Actinopterygii) from lower sections of the Jialing River, south-western China. Acta Ichthyol. Piscat. 48 (3): 315-318.

\begin{abstract}
Length-weight relations (LWRs) were estimated for 46 fish species representing 8 families and 29 genera from the lower sections of Jialing River, a tributary of Yangtze River basin, south-western China: Opsariichthys bidens Günther, 1873; Squaliobarbus curriculus (Richardson, 1846); Ancherythroculter kurematsui (Kimura, 1934); Chanodichthys mongolicus (Basilewsky, 1855); Hemiculter tchangi Fang, 1942; Pseudolaubuca sinensis Bleeker, 1864; Pseudolaubuca engraulis (Nichols, 1925); Parabramis pekinensis (Basilewsky, 1855); Xenocypris davidi Bleeker, 1871; Xenocypris fangi Tchang, 1930; Hypophthalmichthys nobilis (Richardson, 1845); Hypophthalmichthys molitrix (Valenciennes, 1844); Sarcocheilichthys nigripinnis (Günther, 1873); Sarcocheilichthys sinensis Bleeker, 1871; Squalidus argentatus (Sauvage et Dabry de Thiersant, 1874); Coreius heterodon (Bleeker, 1864); Coreius guichenoti (Sauvage et Dabry de Thiersant, 1874); Rhinogobio typus Bleeker, 1871; Rhinogobio cylindricus Günther, 1888; Saurogobio dabryi Bleeker, 1871; Saurogobio gymnocheilus Lo, Yao et Chen, 1998; Gobiobotia filifer (Garman, 1912); Xenophysogobio boulengeri (Tchang, 1929); Onychostoma simum (Sauvage et Dabry de Thiersant, 1874); Spinibarbus sinensis (Bleeker, 1871); Procypris rabaudi (Tchang, 1930); Parabotia fasciata Dabry de Thiersant, 1872; Parabotia bimaculata Chen, 1980; Leptobotia elongata (Bleeker, 1870); Leptobotia taeniops (Sauvage, 1878); Leptobotia rubrilabris (Dabry de Thiersant, 1872); Leptobotia microphthalma Fu et Ye, 1983; Jinshaia sinensis (Sauvage et Dabry de Thiersant, 1874); Pseudobagrus vachellii (Richardson, 1846); Pseudobagrus pratti (Günther, 1892); Tachysurus nitidus (Sauvage et Dabry de Thiersant, 1874); Tachysurus dumerili (Bleeker, 1864); Hemibagrus macropterus Bleeker, 1870; Liobagrus nigricauda Regan, 1904; Liobagrus marginatus (Günther, 1892); Silurus asotus Linnaeus, 1758; Silurus meridionalis Chen, 1977; Glyptothorax fokiensis (Rendahl, 1925); Glyptothorax sinensis (Regan, 1908); Siniperca chuatsi (Basilewsky, 1855); Siniperca knerii Garman, 1912. Data were monthly collected from May 2013 to October 2016. The values of coefficient $a$ ranged from 0.0046 to 0.0237 , and the values of exponent $b$ ranged from 2.66 to 3.26. The length-weight relations of two species have not been previously reported.
\end{abstract}

Keywords: length-weight relations, ichthyofauna, Jialing River, Yangtze River basin

\section{INTRODUCTION}

The Jialing River, with the largest river area (160 000 $\mathrm{km}^{2}$ ) within the Yangtze River basin, is the first tributary on the northern banks of the upper Yangtze River. There are approximately 156 fish species inhabiting the upper Yangtze River basin, including 54 endemic and 12 endangered species (Jiang et al. 2016). The aquatic environment of the Yangtze River basin was gradually damaged by construction of the cascade hydropower stations and excessive dredging, which led to decreasing aquatic biodiversity and fishery resources (Wu et al. 2011). Accurate length-weight relations (LWRs) data are widely used to better understand the species conservation and population dynamics (Ruiz-Campos et al. 2006, Froese et al. 2011), however, the growth data for the endemic fish species are lacking in this key fishery regions. The present study describes the LWRs for 46 common fish species in Jialing River.

\section{MATERIAL AND METHODS}

The study was conducted in the lower sections of Jialing River $\left(29^{\circ} 34^{\prime}-29^{\circ} 59^{\prime} \mathrm{N}, \quad 106^{\circ} 17^{\prime}-106^{\circ} 35^{\prime} \mathrm{E}\right)$, from Hechuan to Chongqing reach, during May 2013October 2016 except the closure period for fishing (between February and April annually). Fish specimens were sampled monthly by drift gillnets (mesh size of 25 $\mathrm{mm}$, knot to knot), stationary gillnets (mesh size of 25 $\mathrm{mm}$, knot to knot), and trawl (mesh size of $30 \mathrm{~mm}$, knot 


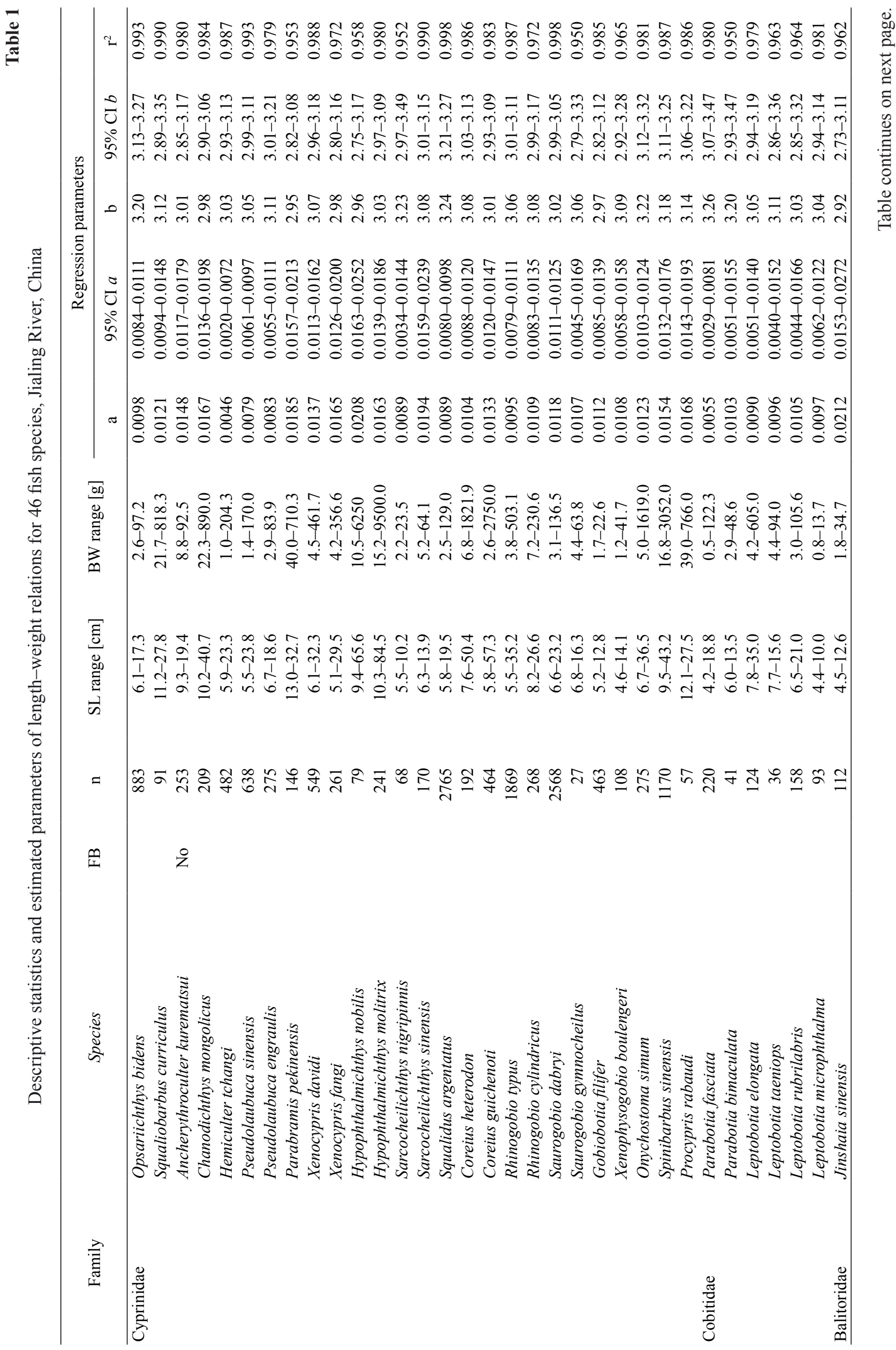




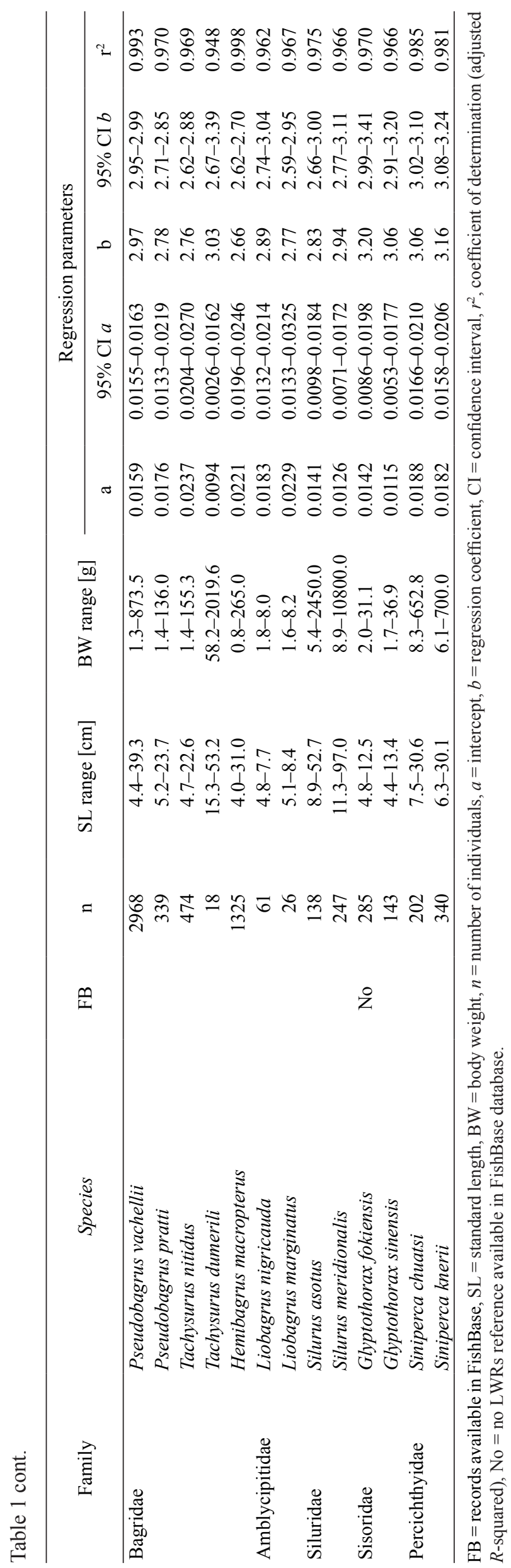

to knot). Fishes were identified to species level based on morphology in the field (Ding 1994), measured for the standard length (SL) and body weight (BW) to the nearest $0.1 \mathrm{~cm}$ and $0.1 \mathrm{~g}$, respectively.

The relations between SL and BW were calculated using the (Ricker 1975) equation

$$
\log W=\log a+b \log L
$$

where $W$ is the body weight (BW, g), $L$ is the standard length (SL, cm), $a$ is the intercept and $b$ is the regression parameters. Prior to regression, log-log plots of the length-weight pairs were performed to detect outliers (Froese 2006). The 95\% confidence interval (CI) for the parameters ( $a$ and $b$ ) and the statistical significance level of $r^{2}$ were estimated. Overall statistical analyses were considered significant at 5\% $(P<0.05)$.

\section{RESULTS AND DISCUSSION}

The LWRs of 21921 individuals from 46 species representing 8 families and 29 genera were determined. The following species were studied: Opsariichthys bidens Günther, 1873; Squaliobarbus curriculus (Richardson, 1846); Ancherythroculter kurematsui (Kimura, 1934); Chanodichthys mongolicus (Basilewsky, 1855); Hemiculter tchangi Fang, 1942; Pseudolaubuca sinensis Bleeker, 1864; Pseudolaubuca engraulis (Nichols, 1925); Parabramis pekinensis (Basilewsky, 1855); Xenocypris davidi Bleeker, 1871; Xenocypris fangi Tchang, 1930; Hypophthalmichthys nobilis (Richardson, 1845); Hypophthalmichthys molitrix (Valenciennes, 1844); Sarcocheilichthys nigripinnis (Günther, 1873); Sarcocheilichthys sinensis Bleeker, 1871; Squalidus argentatus (Sauvage et Dabry de Thiersant, 1874); Coreius heterodon (Bleeker, 1864); Coreius guichenoti (Sauvage et Dabry de Thiersant, 1874); Rhinogobio typus Bleeker, 1871; Rhinogobio cylindricus Günther, 1888; Saurogobio dabryi Bleeker, 1871; Saurogobio gymnocheilus Lo, Yao et Chen, 1998; Gobiobotia filifer (Garman, 1912); Xenophysogobio boulengeri (Tchang, 1929); Onychostoma simum (Sauvage et Dabry de Thiersant, 1874); Spinibarbus sinensis (Bleeker, 1871); Procypris rabaudi (Tchang, 1930); Parabotia fasciata Dabry de Thiersant, 1872; Parabotia bimaculata Chen, 1980; Leptobotia elongata (Bleeker, 1870); Leptobotia taeniops (Sauvage, 1878); Leptobotia rubrilabris (Dabry de Thiersant, 1872); Leptobotia microphthalma Fu et Ye, 1983; Jinshaia sinensis (Sauvage et Dabry de Thiersant, 1874); Pseudobagrus vachellii (Richardson, 1846); Pseudobagrus pratti (Günther, 1892); Tachysurus nitidus (Sauvage et Dabry de Thiersant, 1874); Tachysurus dumerili (Bleeker, 1864); Hemibagrus macropterus Bleeker, 1870; Liobagrus nigricauda Regan, 1904; Liobagrus marginatus (Günther, 1892); Silurus asotus Linnaeus, 1758; Silurus meridionalis Chen, 1977; Glyptothorax fokiensis (Rendahl, 1925); Glyptothorax sinensis (Regan, 1908); Siniperca chuatsi (Basilewsky, 1855); Siniperca knerii Garman, 1912. The most abundant species included Pseudobagrus vachellii, Squalidus 
argentatus, and Saurogobio dabryi. The values of coefficient $a$ ranged from 0.0046 (Hemiculter tchangi) to 0.0237 (Tachysurus nitidus), and the values of exponent $b$ ranged from 2.66 (Hemibagrus macropterus) to 3.26 (Parabotia fasciata). The coefficient of determination values $\left(r^{2}\right)$ in the majority of LWRs were high $\left(r^{2}>0.938\right)$.

The $b$ values represented the range expected for teleost species between 2.5 and 3.5 (Froese 2006). Additionally, the LWRs for two species were determined for the first time (indicated in Table 1): Ancherythroculter kurematsui and Glyptothorax fokiensis according to FishBase (Froese and Pauly 2018).

In conclusion, it is the first time to study the LWRs for the species in Jialing River. The results in this study provide significant information in this area for scientists and managers which can help them monitor growth conditions and estimate species population dynamics for management and conservation purposes.

\section{ACKNOWLEDGEMENTS}

The authors wish to thank the colleagues: Shalong Zhang, Wei Wang, Lei Li, Huanchao Yang, Zhihua Hu, and Wen Song for their assistance in the fieldwork.

\section{REFERENCES}

Ding R.H. 1994. [The fishes of Sichuan Province.] Sichuan Publishing House of Science and Technology, Chengdu, China. [In Chinese.]
Froese R. 2006. Cube law, condition factor and weightlength relationships: History, meta-analysis and recommendations. Journal of Applied Ichthyology 22 (4): 241-253. DOI: 10.1111/j.1439-0426.2006.00805.x

Froese R., Pauly D. (eds.) 2018. FishBase. [Version 06/2018] www.fishbase.org

Froese R., Tsikliras A.C., Stergiou K.I. 2011. Editorial note on weight-length relations of fishes. Acta Ichthyologica et Piscatoria 41 (4): 261-263. DOI: 10.3750/AIP2011.41.4.01

Jiang Z.G., Jiang J.P., Wang Y.Z., Zhang E., Zhang Y.Y. 2016. [Red List of China's Vertebrates.] Biodiversity Science 24: 500-551. [In Chinese.]

Ricker W.E. 1975. Computation and interpretation of biological statistics of fish populations. Bulletin of the Fisheries Research Board of Canada No. 191.

Ruiz-Campos G., González Acosta A.F., De La Cruz Agüero J. 2006. Length-weight and lengthlength relationships for some continental fishes of northwestern Baja California. Mexico. Journal of Applied Ichthyology 22 (4): 314-315. DOI: 10.1111/j.1439-0426.2006.00780.x

Wu J., Wang J., He Y., Cao W. 2011. Fish assemblage structure in the Chishui River, a protected tributary of the Yangtze River. Knowledge and management of aquatic ecosystems 400: e11. DOI: 10.1051/ $\mathrm{kmae} / 2011023$

Received: 19 September 2017

Accepted: 3 August 2018 Published electronically: 30 September 2018 